\title{
Finnegans Wake e seus personagens tradutores
}

Dirce Waltrick do Amarante

Num ensaio intitulado "Ajudantes", o filósofo italiano Giorgio Agamben (dialogando com idéias desenvolvidas por Walter Benjamin no ensaio "Franz Kafka") fala sobre seres que "não sabemos quem são, talvez sejam 'enviados' do inimigo (o que explica por que insistem em ficar à espreita e espiar). Mesmo assim, assemelham-se a anjos, a mensageiros que desconhecem o conteúdo das cartas que devem entregar, mas cujo sorriso, cujo olhar e cujo modo de caminhar 'parecem uma mensagem'"1.

Poderíamos descrever os personagens de Finnegans Wake (1939), romance "noturno" de James Joyce (1882-1941), como esses "ajudantes", descritos acima. Um dos habitantes do sonho joyceano é, aliás, um carteiro, Shaun, ou "Shaun Mac Irewick, briefdragger"', o desenterrador de fatos [FW 126], cuja função é tornar público um documento do qual ele não é nem autor, nem conhecedor dos fatos ali descritos. A propósito da função de Shaun na narrativa de Joyce, Donaldo Schüler, tradutor do romance para o português, afirma que “no papel de carteiro, Mercúrio, Tot, lua, papa, ou Cristo, Shaun

\footnotetext{
AGAMBEN, Giorgio. Profanações. Trad. de Selvino Assmann. São Paulo: Boitempo, 2007, p. 31.

2 Em alemão, "carteiro" é Biefträger.
} 
não passa de mensageiro, portador de uma luz que não vem dele. Isso lhe dói, os leitores fazem perguntas". ${ }^{3}$

Os ajudantes do sonho, ou pesadelo, de Joyce seriam essencialmente criaturas "crepusculares", semelhantes às personagens da obra de Franz Kafka analisadas por Walter Benjamin no ensaio mencionado acima: "nenhuma delas tem lugar fixo nem contornos claros e inconfundíveis; nenhuma que não pareça prestes a subir ou a cair; nenhuma que não se possa confundir com seu inimigo ou com seu vizinho; nenhuma que não tenha completado sua maioridade e que, no entanto, [não] seja imatura; nenhuma que não esteja completamente exausta, e, contudo, ainda [não] esteja no começo de uma longa viagem. Não se pode sequer falar de ordens ou de hierarquias" ${ }^{4}$.

Tim Finnegan, personagem de uma canção popular que dá título ao último livro de Joyce, por exemplo, é uma dessas criaturas "crepusculares" que entra e sai da história sem que saibamos quem de fato é. Segundo Joseph Campbell e Henry Morton Robinson, "o divertido episódio de Finnegan é apenas o prólogo de uma ação maior." 5 Já para Michel Butor, "a história de Finnegan (...) se apresenta sob uma enorme amplificação e dá nascimento a muitas outras espécies de narrativas, através das quais se discernem pouco a pouco as constantes que definirão H.C.E." ${ }^{\prime}$, sendo H.C.E. (Here Comes Everyboby) o "herói" do livro.

Tim Finnegan desaparece nas primeiras páginas do romance. Completamente "exausto", ele abandona a sua longa jornada logo no início. Outros personagens tomam o seu lugar, H.C.E., Anna Livia

JOYCE, James. Finnegans Wakel Finnicius Revém. Volume 5. Trad. de Donaldo Schüler. São Paulo: Ateliê Editorial, 2003, p. 67.

4 BENJAMIN, Walter. A Modernidade e os Modernos. Trad. de Heindrun Krieger Mendes da Silva, Arlete de Brito e Tânia Jatobá. Rio de Janeiro: Tempo Brasileiro, 1975, p. 83.

5 CAMPBELL, Joseph e ROBINSON, Henry Morton. A Skeleton Key to Finnegans Wake. Nova York: Buccaneer Books, 1976, p. 15.

6 BUTOR, Michel, Repertório. Trad. e org. de Leyla Perrone-Moysés. São Paulo: Perspectiva, 1974, p. 163. 
Plurabelle, sua mulher, seus filhos, Shem e Shaun, os quais também desaparecem e reaparecem em metamorfoses contínuas, razão pela qual diria que, assim como os "ajudantes", esses personagens também não conseguem "concluir nada e ficam geralmente sem ter o que fazer." 7

Para exemplificar a tese acima, cito um breve resumo que Donaldo Schüler fez do capítulo treze do Wake: "No sonho", diz Donaldo, "o bar fez-se barco, o barco se faz leito conjugal. Shaun, em que se concentra a ação, é um barril levado pela correnteza, é uma caixa repleta de cartas, é Diógenes em busca de um homem ou de uma verdade, é Cristo em cuja via crucis de catorze estações se formulam outras tantas perguntas. O movimento é textual, passa por perguntas e respostas" .8

Sem uma função específica, exceto a de surgirem "no momento de perigo", os ajudantes são esses personagens que, segundo Agamben, "o narrador esquece no final da narrativa, quando os protagonistas vivem felizes e contentes até o final de seus dias; mas deles, dessa 'gentalha' inclassificável à qual, no fundo, devem tudo, já não se sabe nada. No entanto, tentem perguntar a Próspero, quando demitiu todos os seus encantos e retornou, com os outros seres humanos, a seu ducado, o que é a vida sem Ariel". 9

Mas, em se tratando de Finnegans Wake, quem são de fato seus protagonistas? Na opinião de Adaline Glasheen é difícil identificar os protagonistas da obra de Joyce, ou quem viverá feliz para sempre, pois "um ator interpreta muitos papéis ao mesmo tempo", de modo que os personagens de Wake "são indicações frágeis (não modelos) de um processo amplo, denso, construído de maneira elaborada e em movimento perpétuo de variação regular, como estrelas, átomos, subátomos, células e galáxias: quem exatamente você

$7 \quad$ AGAMBEN, Giorgio. Op. Cit., p. 31, 32.

8 JOYCE, James. Finnegans Wakel Finnicius Revém. Trad. de Donaldo Schüler. Volume 2. São Paulo: Ateliê Editorial, 2000, p. 11.

9 AGAMBEN, Giorgio. Op. cit., p. 32. 
Dirce Waltrick do Amarante. Finnegans Wake e seus personagens tradutores

disse que é é quem quando... (sic)?"10. Os personagens surgem em Wake como surgem em nossos sonhos, sem precisão nem clareza. Como disse Carlos Drummond de Andrade, "a noite dissolve os homens".

Além desse caráter onírico de Finnegans Wake, responsável pela "dissolução" de seus personagens, o livro não tem um ponto final (mas desde quando os sonhos têm um ponto final?), portanto, nessas condições, qual personagem, poderíamos indagar, vive "feliz e contente até o final dos seus dias"? Desse modo, pergunto-me se, em Finnegans Wake, não seriam todos os personagens apenas ajudantes, que circulam na narrativa a serviço da linguagem, essa sim a grande protagonista do livro?

A respeito da linguagem do Wake, William York Tindall afirma que o último romance do escritor irlandês "não é sobre ninguém, nenhum lugar, nenhuma época."11 Seguindo essa tese, estudiosos têm afirmado, ao longo dos anos, que o romance nada mais é do que "um sonho sobre a linguagem"12, ou que "o verdadeiro romance se passa entre Joyce e a linguagem"13. Razão pela qual, Umberto Eco, ao se referir às traduções de Finnegans Wake realizadas pelo próprio Joyce, afirmou que, mesmo para o autor/tradutor, "o tema era pretexto" ${ }^{14}$, já que aquilo que ele procurava resguardar era "o princípio fundamental que rege o Finnegans Wake, ou seja, o princípio do pun e do mot-valise", isto é, Joyce procurava traduzir não a história do romance, mas a sua própria experimentação com a linguagem. ${ }^{15}$

10 GLASHEEN Adaline, Third Census of Finnegans Wake: an Index of the Characters and Their Roles. Berkeley \& Los Angeles: University of California Press, 1977.

11 TINDALL, William York. A reader's guide to Finnegans Wake. Nova York: Syracuse University Press, 1996, p. 3.

12 BUTOR, Michel. Op. Cit., p. 155.

13 CAMPOS. Augusto de. Poesia, Antipoesia, Antropologia. São Paulo: Cortez \& Moraes, 1978, p. 9.

14 ECO, Umberto. Quase a mesma coisa. Trad. de Eliana Aguiar. Rio de Janeiro: Record, 2007, p. 363

15 Idem, p. 358. 
A propósito da linguagem do Wake, compararia a mesma ao Odradek, personagem de Kafka, "feito de linha, mas de pedaços de linha, cortados, velhos, emaranhados e cheios de nós, de tipos e cores diferentes". ${ }^{16}$ Segundo Walter Benjamin, "Odradek é a forma que as coisas assumem no esquecimento. Desfiguram-se, tornam-se irreconhecíveis", tal como ocorre, a meu ver, à linguagem de Finnegans Wake. Se Odradek, que ninguém sabe o que é, é "a preocupação do pai de família"17, a língua do Wake, incompreensível, é o centro do romance. No capítulo cinco do livro, lemos (na tradução de Donaldo Schüler): "Sentes-te perdido como num matagal, menino? Dizes: Isso não é mais que puro e simples emiranhado de palavras: Macacos que me merdem se tenho a mais franga noção do sentido desse emmorrinhado todo" [FW 112]..$^{18}$

Nesse contexto, os ajudantes do Wake teriam a função de traduzir a língua do romance joyceano, numa situação parecida à dos ajudantes de As mil e uma noites, mencionados por Agamben, os quais "foram escolhidos entre os não-árabes; são estrangeiros entre os árabes, embora falem sua língua". Os personagens de Finnegans Wake, a despeito de serem irlandeses, são estrangeiros na Irlanda, "colônia britânica", e, pelo fato de circularem por duas culturas diferentes e duas línguas diferentes (ou mais culturas e línguas, já que, antes dos ingleses, chegaram, na Irlanda, os viquingues, os franceses...), estariam mais aptos a traduzirem um livro com sintaxe inglesa, mas repleto de falares e culturas diversas.

Sobre os ajudantes, Agamben afirma ainda que "uma de suas qualidades é a de serem 'tradutores' (mutarjim) da língua de Deus para a língua dos homens". O filósofo italiano prossegue citando Ibn-Arabi, autor de Iluminações de Meca, segundo o qual "todo mundo nada mais é que uma tradução da língua divina, e os ajudantes,

16 BORGES, Jorge Luis. O Livro dos Seres Imaginários. Trad. Carmen Vera Cirne Lima. Porto Alegre, 1974, p. 132.

17 BENJAMIN, Walter. Op. Cit., p. 99.

18 JOYCE, James. Finnegans Wake/ Finnicius Revém. Volume 3. São Paulo: Ateliê Editorial, 2001, p. 29. 
nesse sentido, são os realizadores de teofania interminável, de uma revelação contínua". ${ }^{19}$

Em Wake, os personagens se esforçam para traduzir o tempo todo aquilo que é intraduzível, que é inatingível. Os ajudantes preparam nosso "Reino", mas "reinar", diz Agamben, "não significa satisfazer. Significa que o insatisfeito é o que permanece".$^{20}$

Em Finnegans Wake, lembra Donaldo Schüler, "como escrita, Shaun desvela e esconde. A escrita, colocando-se em lugar de ausentes, distancia, mata. Mas é na mesma escrita que os mortos retornam como remembrândtias, obras de arte, imagens recolhidas e distribuídas por Shaun, o carteiro. O texto literário (de que Shaun é a superfície que divulga) mata HCE e ALP, guardados no esquife literário. Só na literatura HCE revém, só na literatura ALP é Anastásia, a Ressurreta". ${ }^{21}$

O ajudante seria, então, "a figura daquilo que se perde, ou melhor, da relação com o perdido". Ele representa a lacuna da tradução, a relação com o que se perdeu, sendo que "o perdido não é para ser lembrado ou satisfeito, mas continuar presente em nós como esquecido, como perdido e, unicamente por isso, como inesquecível. Em tudo isso", conclui Agamben, "o ajudante é de casa. Ele soletra o texto do inesquecível e o traduz para a língua dos surdos-mudos", gesticulando, movimentando-se, pois "do inesquecível só é possível a paródia"22, ou seja, na tradução, o que se perde só na paródia se recupera.

Mas, no romance de Joyce, afirma Schüler que, "dispersos, resignamo-nos com a perda do que se passa além de nossos horizontes ou ensaiamos a dolorosa marcha de retorno, enredados na imensidão efervescente do que não é nosso." ${ }^{23}$

\footnotetext{
AGAMBEN, Giorgio. Op. Cit., p. 34.

Idem, p. 35.

21 JOYCE, James. Finnegans Wakel Finnicius Revém. Volume 5. São Paulo: Ateliê Editorial, 2003, p. 65, 66.

22 AGAMBEN, Giorgio. Op. Cit., p. 35.

23 JOYCE, James. Finnegans Wake/ Finnicius Revém. Volume 2. São Paulo: Ateliê Editorial, 2000, p. 19.
} 
Por outro lado, quem relata também "não entende o que divulga. Busca alucinadamente socorro em teorias e obras de vária natureza. O que poderia ser enfadonha erudição mostra-se insaciável carência." ${ }^{24}$

Finnegans Wake constitui, desse modo, um esforço para se entender a natureza da língua do sonho. Mais do que isso, o livro, parece-me, suscita uma reflexão sobre a linguagem e a literatura como possibilidades de revelação da "verdade", verdade essa, segundo Maurice Blanchot, inatingível: "A linguagem só começa com o vazio; nenhuma plenitude, nenhuma certeza, fala; para quem se expressa falta algo essencial. A negação está ligada à linguagem. No ponto de partida, eu não falo para dizer algo; é um nada que pede para falar, nada fala, nada encontra seu ser na palavra, e o ser da palavra não é nada. Essa fórmula explica por que o ideal da literatura pôde ser este: nada dizer, falar para dizer nada". ${ }^{25}$

Em meio a essas carências, o ajudante/tradutor se esforça "para manter próximo de si um original cada vez mais distante, uma protoimagem (Urbild), completamente perdida." ${ }^{26}$ Ele lança seu olhar, como diz Walter Benjamin num outro contexto, "sobre a ambiguidade das passagens: sua riqueza de espelhos que aumenta os espaços de maneira fabulosa e dificulta a orientação. Ora, este mundo de espelhos pode ter múltiplos significados e até mesmo uma infinidade deles - permanecendo sempre ambíguo". Aos ajudantes não cabe mais nada a fazer. ${ }^{27}$

24 Idem ibidem.

25 BLANCHOT, Maurice. A Parte do Fogo. Trad. de Ana Maria Scherer. Rio de Janeiro: Rocco, 1997, p. 312.

26 ANTELO, Raúl. Tempos de Babel: anacronismo e destruição. São Paulo: Lumme, 2007, p. 48,49 .

27 BENJAMIN, Walter. Passagens. Org. de Willi Bolle; colaboração na organização Olgária Chain Féres Matos; trad. do alemão de Irene Aron; trad. do francês de Cleonice Paes Barreto Mourão. Belo Horizonte: UFMG; São Paulo: Imprensa Oficial do Estado de São Paulo, 2006, p. 583. 